\title{
STATE AND DEVELOPMENT OF INDUSTRIAL AND PUBLIC SECTOR IN COMPARISON OF GREECE WITH THE REST OF THE WORLD
}

\author{
Kyriaki Papadopoulou ${ }^{1}$
}

Received: 25.05.2020, Accepted: 11.08.2020

\section{Abstract}

The present study aims at critically accessing and comparing the state and the development of the industrial and the public sector of Greece with the rest of the world. It was found that the Greek economy has faced many ups and downs. Starting from the launch of the euro as the local currency to the massive destruction caused by the financial crisis of 2007. Public and industrial sector of Greek even after witnessing all these major events has been able to establish a good growth trajectory in comparison to the rest of the world. The economy showed strong growth in terms of its manufacturing sector. With food and beverages sector, pulp and paper sector, petroleum and refinery standing out as the major manufacturing industries. While the structural reform taken place in the public sector of Greece helped it to maintain its position in comparison with the rest of the world.

Keywords: state and development, public sector, industrial sector, Greece, Greek economy

JEL Codes: E2, F6, O11.

\section{Introduction}

Greece which is known as the cradle of the western civilization has witnessed a tumultuous history. The economy has survived the period of authoritarian regimes to the military regimes as well. With Greece becoming the tenth member of European community in the year 1981, it has witnessed a period of intense prosperity. The launch of the Euro as the local currency provided the passage towards the modernization of the economy.

\footnotetext{
${ }^{1}$ Faculty of Economics, South-West University "Neofit Rilski”, 6, Ivan Mihavlov str, 2700 , Blagoevgrad, Bulgaria, PhD student, e-mail: koutsogiannik1985@gmail.com; ORCID ID: https://orcid.org/0000-0002-3526-4247
} 
However, the financial crisis of 2007 that started from US and quickly spread globally had a profound destructive impact in Greece (Ozturk \& Sozdemir, 2015). Abboushi S., in his report (Abboushi, 2011) mentioned that the financial crisis was not the only reason behind the deterioration of the Greek economy. It was majorly due the gaps in the economic and the financial structure of the economy such as financial extravagancy, insufficiency of the Greece government, unfair taxation that aggravated the situation.

The public and industrial sectors of Greece have evolved substantially under these circumstances. The public sector of Greece has conventionally followed three major goals. The first and the primary idea is to reduce the state presence in the economy through liberalizing the markets or by contraction of the public ownership. The second major objective that shapes the public sector of Greece is to reduce the excessive proximity of the public corporations with the politics. The major reason behind this is to reduce their exploitation by the political parties in the form of employment reserves. And finally, rationalization of the state activities (Spanou, 2008).

The state and development of the industrial sector of an economy plays a decisive role in the achievement of sustainable socioeconomic development (Hussin \& Ching, 2013; OECD, 2008). The secondary or the industrial sector of Greek has faced a lot of revamping with its vigorous shift towards the industrialization. The major development of the Greek industrial sector can be attributed to the quantitative enlargement that has been achieved by the manufacturing sector there (Chalikias, 2017). In fact, the manufacturing sector in Greece has taken over the agricultural sector in terms of its contribution to the GDP (Linardos, 2015). The sections ahead will provide and elaborate view on the state and development in the industrial and the public sector of Greece. The aim of the study is to critically access and compare the state and the development of the industrial and the public sector of Greece with the rest of the world.

\section{Literature review}

The idea of state effectiveness as the key factor that encourages economic development is not new. There are various things that comes under the state work responsibilities such as providing public goods, correcting the market failures, reducing the inequality in terms of income and opportunities, stabilizing the economic fluctuations (Tabellini, 2005). However, these factors are not the only ones that makes difference between the success and the failure in the economic development. Rather what makes the real difference is the institutional and the legal infrastructure that protects the property right, enforces the rule of law that 
affects the development (Tabellini, 2005). Thus, the state's essential role in harnessing the national resources and further directing them appropriately by using distinctive policy making system is what affects the development of the economy (Dadzie, 2013). Moreover, the development in the form of the industrialization requires capital and coordination at different levels (Kniivilä, 2007). What is majorly required is that markets need to be harnessed so that they can act in the long-term national interest rather than for the short-term individual interest. And state stands as the only one contemporary institution that is capable of such kind of coordination (Wylde, 2017).

Lange M. in his study (Lange, 2005) mentioned the point of view of Adam Smith on the state and development. According to him states are essential for the development and the social transformation. Because the state can enable the institutions and the individuals to engage in the economic activities that can possibly bring development for the economy. States by providing the infrastructural support in term of the contracts, property law, incorporations that allows the exchange of goods and services, lending and investing so that they can proceed with certain degree of ease, security and predictability helps in bringing in development. Further (Bardhan, 2016) mentioned another important explanation provided by Adam Smith is that states are of great importance when it comes to bringing in the socioeconomic development. And provided two possible reasons for this: first is that state works towards breaking down the resistance in the market, second reason is that state through its regulations and social policies moderate the impact of the market and thus led to sustainable market economy.

The present study is based on secondary research. (Martins, Cunha, \& Serra, 2018) defined secondary data as the dataset which is not obtained by researcher himself rather the data gathered by someone else. The secondary data sources for the present study includes business reports, books, publications, articles in magazines and journal articles.

\section{Discussion}

\subsection{State and development of the industrial and public sector of Greece}

The industrial sector of Greece had witnessed a lot of revamping majorly due to its shift towards industrialization. In, fact in the last few years the manufacturing sector has risen as the core segment of the Greek industrial sector with its contribution exceeding the agricultural sector in terms of its contribution towards GDP (OECD, 2012). (EU-MERCI, 2014) mentioned about the major manufacturing industries that have the major contribution in the Greek industrial 
sector. This includes the food and beverages sector, pulp and paper sector, petroleum refineries sector.

With food and the beverages sector marked as the pillar of the Greek manufacturing industry due to its contribution in terms of turnover and increased employment. (EU-MERCI, 2018) mentioned that there is almost 15000 food and beverages firms currently operating in Greece which provides employment to around 80,000 people and had average turnover of around USD 11.66 million. Another major industry operating in Greece is the paper and pulp industry. In the year 2014 there were around 641 active paper and pulp companies in Greece. Which consisted of three major subsectors that includes manufacture of pulp, paper and paperboard, manufacturer of paper and paperboard and manufacture of pulp. The sectors combinedly provided employment to around 6.938 people (EUMERCI, 2014).

Next is the petroleum refinery sector with its main concentration on the manufacturing of the coke and the petrol products. The industry was divided into three major subsectors with one sector focusing on the manufacturing of the coke oven products, manufacturing of coke and refined petroleum products and the other sector focusing on the manufacturing of the refined petroleum products. Further it was found that there were around 42 companies that were active manufacturers of coke and petroleum products which provided employment to around 4,000 people (Kalampalikas \& Pilavachi, 2006).

The public sector of Greece, on the other hand, has had a tumultuous history. With the economy of Greece witnessing a change from an authoritarian regime to a military regime, the country's public sector has been built under volatile circumstances. Greece technically began with its public sector reforms straight after its EU accession but came to the halt with the rise of the military power in the country (Manojlović, 2011). The first official attempt to bring in reforms was made in year 1980s. The second series of the reforms was launched in the period 1991-2000. In this time period Greece was faced many financial difficulties and thus reforms were taken in order to reduce the budget deficit. Further between the year 2001 and 2009 when Greece was economically stable some more visible reforms were carried out. And then finally after the year 2010 (Chardas, 2011).

The key idea behind the public sector reforms was based on its modernization which was necessary to ensure the high-quality provision of public goods and services. The main aim of the reforms was to unify the wage levels among the public officials, establishment of the transparent and merit based recruitment system, introduction of the mobility and the performance assessment, 
improvement of the countries judicial system, strengthening of the tax system within the country and finally focusing on better management of the public sector entities (Centre of Planning and Economic Research, 2019). With the reforms in its public administration, judicial system and the tax collection system. The public sector of Greece has able to provide employment to around 700,000 people. Further in an report published by (OECD, 2017) it was found that Greece is spending around $54.2 \%$ of its total GDP on its public sector which however decreased in the period pertaining to 2015 to 2016 to $49 \%$.

\subsection{Rest of the world}

The following section focuses on providing the brief comparison between the state and development within the Greece with the rest of the world. With the convergence of Greece with the euro zone what followed seemed to be a success story. Although the country had witnessed some major breakdowns due to the global financial crises but its public sector and the industrial sector has still managed to play well in between of all the circumstances (Neubaumer, 2015).

Figure 1: Comparison of Greek economy with the rest of the world

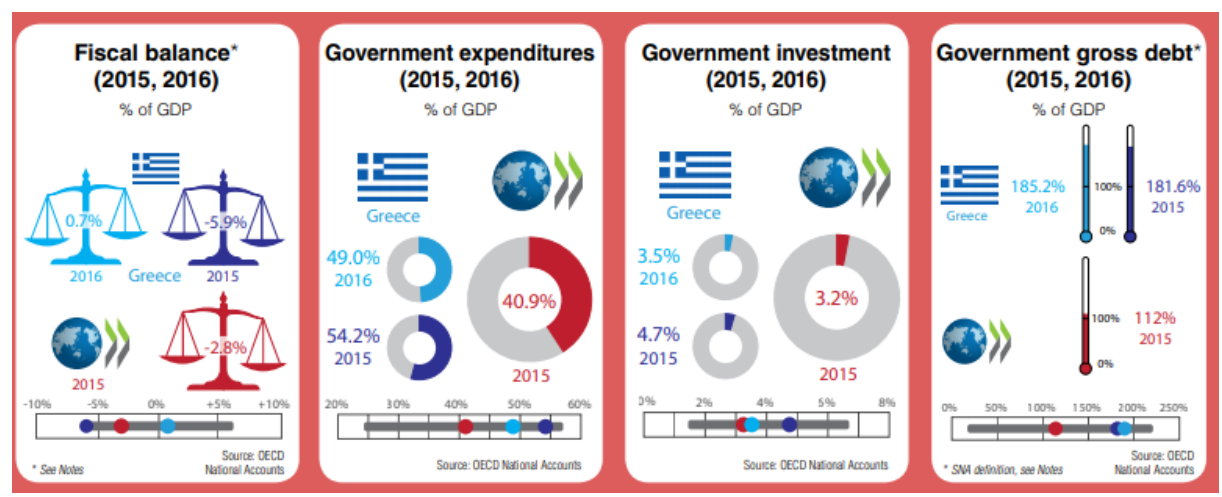

Source: OECD, 2017

The figure above represents the comparison of the Greek economy with the rest of the world in terms of certain parameters such as fiscal balances, their average government spending on the public sector, the investment by the government, and the finally the gross debt faced by the government. As shown in the above figure Greece due to its reforms adopted in different time period has been able to compete with the rest the world very well. Further the economy has been able to maintain strong position in terms of their average expenditure on the 
public sector. Since the development of the public sector plays a crucial role in the overall development of the economy.

\section{Conclusion}

The present study aimed at accessing and comparing the state and the development of the industrial and the public sector of Greece with the rest of the world by using secondary research approach. It was established that Greek economy had faced many ups and downs over the time period. Starting from its EU accession that the economy witnessed in the year 1981 and its convergence with the euro zone. The GDP of the economy increased by an average of 4.2 percent and what followed was the sustainable environment and intense prosperity. But soon it was established that it was just a false illusion. With the financial crisis outbreak that happened in US in the year 2007, the Greek economy faced major deterioration. The situation highlighted the various gaps in the economic and the financial structure of the economy such as financial extravagancy, insufficiency of the Greece government, unfair taxation. However, with its shift towards the industrialization the industrial sector of Greece had witnessed a lot of revamping. The economy showed strong growth in terms of its manufacturing sector. Further the structural reform taken place in the public sector of Greece helped it to maintain its position in comparison with the rest of the world. Future studies in this topic could include comparison of the Greece with the other OECD countries so that the picture regarding the current state and development of the Greece could become even clearer and could further help with the policy making decisions.

\section{REFERENCES}

Abboushi, S. (2011). Analysis and Outlook of the Greek Financial Crisis. Journal of Global Business Management, 7(1), 1-8.

Bardhan, P. (2016). State and development: The need for a reappraisal of the current literature. Journal of Economic Literature, 54(3), 862-892. https://doi.org/10.1257/jel.20151239

Centre of Planning and Economic Research. (2019). Structural reforms in Greece, 2010-2018. (April). https://doi.org/10.2873/100377

Chalikias, J. (2017). The Manufacturing Sector of Greece Before and During the financial Crisis. International Journal of Economics and Business Administration, 5(1), 3-17.

Chardas, A. (2011). How the EU affects domestic institutional capacities : the Europeanisation of Greece 's administrative system in the context of the EU 
's Regional Policy.

Dadzie, R. B. (2013). Economic Development and the Developmental State. Journal of Developing Societies, 29(2), 123-154. https://doi.org/10.1177/0169796x13479711

EU-MERCI. (2014). Analysis of the industrial sectors in different countries: Greece. (693845), 1-36.

EU-MERCI. (2018). Analysis of the industrial sectors in different countries: Greece. (693845), 1-36.

Hussin, F., \& Ching, C. W. (2013). The Contribution of Economic Sectors to Economic Growth: The Cases of Malaysia and China. International Journal of Academic Research in Economics and Management Sciences, 2(2), 3648.

Kalampalikas, N., \& Pilavachi, P. (2006). The energy policy of Greece. Thermal Science, 10(3), 7-18. https://doi.org/10.2298/tsci0603007k

Kniivilä, M. (2007). Industrial development and economic growth: Implications for poverty reduction and income inequality. In Industrial Development for the 21st Century: Sustainable Development Perspectives (pp. 295-332). New York: United Nations, Department of Social and Economic Affairs.

Lange, M. (2005). States and development.

Linardos, P. (2015). The Development of Industry in Greece 1990-2014 and possible future action for the left industrial policy by Petros Linardos Rulmond and Savvas Robolis February 2015. (February).

Manojlović, R. (2011). Public Sector Reforms in Greece: Uncertain Outcome of 2010 Reforms. Hrvatska i Komparativna Javna Uprava, 11(2), 337-377.

Martins, F. S., Cunha, J. A. C. da, \& Serra, F. A. R. (2018). Secondary Data in Research - Uses and Opportunities. Revista Ibero-Americana de Estratégia, 17(04), 01-04. https://doi.org/10.5585/ijsm.v17i4.2723

Neubaumer, R. (2015). The prologue to the greek crisis.

OECD. (2008). THE CONTRIBUTION OF SERVICES TO DEVELOPMENT AND THE ROLE OF TRADE LIBERALISATION AND REGULATION. UK.

OECD. (2012). Greece at a Glance: Policies for a Sustainable Recover. Oecd, $01-20$.

OECD. (2017).Government at a Glance 2017 https://dx.doi.org/10.1787/gov_glance-2017-en

Ozturk, S., \& Sozdemir, A. (2015). Effects of Global Financial Crisis on Greece 
Economy. Procedia Economics and Finance, 23(January), 568-575. https://doi.org/10.1016/s2212-5671(15)00441-4

Spanou, C. (2008). State reform in Greece: Responding to old and new challenges. International Journal of Public Sector Management, 21(2), 150173. https://doi.org/10.1108/09513550810855645

Tabellini, G. (2005). The role of the state in economic development. Kyklos, 58(2), 283-303. https://doi.org/10.1111/j.0023-5962.2005.00289.x

Wylde, C. (2017). Emerging Markets and the State. Emerging Markets and the State, 15-43. https://doi.org/10.1057/978-1-137-55655-4 